\title{
SUPERVISION FOR ADVOCACY: SUPPORTING SELF-CARE
}

\author{
KATHLEEN J. FARKAS ${ }^{1} \&$ JAROSŁAW RICHARD ROMANIUK ${ }^{2}$ \\ ${ }^{1}$ Case Western Reserve University, Jack, Joseph and Morton Mandel School of Applied Social Sci- \\ ences, 11235 Bellflower Road, Cleveland, Ohio 44109, USA. ORCID: 0000-0002-1937-3603, Email: \\ kjf@case.edu \\ ${ }^{2}$ Case Western Reserve University, Jack, Joseph and Morton Mandel School of Applied Social Sci- \\ ences, 11235 Bellflower Road, Cleveland, Ohio 44109, USA. ORCID: 0000-0002-8568-6587, Email: \\ jir3@case.edu
}

ABSTRACT: The objective is to examine the intersection of advocacy for social change, the individual's emotional costs of advocacy, and the use of trauma informed care in supervisory practice to encourage and support advocates and their work. Supervision models exist, but none address the needs of advocates who might become targets for scorn and persecution. The literature on trauma informed care provides a direction to improve the support and supervision of advocates, especially those who use their personal experiences as examples in their work. We reviewed data bases and relevant literature regarding supervision and the principles of trauma informed care. Periodical literature was reviewed for examples of those affected personally and professionally by their advocacy efforts. Review of the literature revealed little new knowledge on social work supervision but provided a base to apply the principles of trauma informed care to support and encourage advocacy for social change. This paper suggests the use of trauma informed care in supervisory relationships and advocacy work. This is an original approach to encourage and uphold advocates in difficult times. KEYWORDS: Social work, social identity, trauma informed, reflective supervision 


\section{INTRODUCTION AND OVERVIEW OF SUPERVISION}

$\mathrm{O}$ ne way to begin our topic is to clarify what we mean when we use the term "supervision”. Bernard and Goodyear described supervision as an intervention provided by a more senior member of a profession to a more junior one of that same profession (2004). As in intervention, supervision becomes a tool with an established beginning, middle, and end; it can continue over time and can be focused on a set of specific outcomes and indicators. Used as an intervention, supervisory relationships are intentional and can be evaluated using various indicators and outcomes. Supervision takes place at various levels in the United States and involves students in training, young professionals seeking licensure, mid-career professionals, and mature experienced professionals. Supervisors who are entrusted with students and interns are responsible for socializing these trainees into the values and skills of the profession. These supervisors often find themselves serving as gatekeepers for the profession by differentiating between those students who perform well and those who need remedial work prior to graduation. Student supervision can provide professional fulfillment and an outlet for creativity and interests, as well as a feeling of adding to the growth of the profession. Supervisory intervention helps to enhance the skills of emerging practitioners, to ensure provision of high quality service to clients, and to prepare the emerging practitioners for successful licensure. Licensed professionals can then move into a supervisory role as well as participate in peer supervision with senior colleagues. Among licensed professionals, supervision is often more collegial as opposed to having any authority or responsibility for performance. Client outcomes and service quality remain the goals of supervisory practices at any level.

Supervisors play a number of roles within their organizations, among their staff, and within their professions (Bernard \& Goodyear 2004). Supervisors are engaged in furthering the goals of the agency as well as improving programs and services. They may be active in advocacy and governance roles in addition to the supervisory tasks with students and interns. There is a tension between the pleasurable aspects of educating and guiding students and junior colleagues and the demands of other supervisory roles. Budgets, resources, deadlines and other demands on a supervisor's time and energy can seriously impinge upon the relationship between the supervisor and the supervisee. There can be less time and fewer resources to spend on supervisory tasks, as inviting as they may be, when additional time and attention are needed to address the needs of emerging professionals. Many of these supervisory demands are associated with the dictates of agencies and bureaucracies, so diverse forms of social work supervision were developed across different countries and social welfare systems (Wonnacott 2011; Grewiński \& Skrzypczak 2014). The conflict between conservative (managerial) and critical social work approach is discussed by many authors (see Timor-Shlevin \& Benjamin 2021). In addition to an increased role of critical social work and awareness of the role of oppression in today's society, it is clear that traumatic experiences are prevalent among those served (Anda et al. 2006). As a result, special trauma informed care was developed in the past twenty years to meet the needs of those who struggle (SAMHSA 2014). This care is needed by both the clients 
who come to us in need and the social workers who serve them.

One of the realities of student and intern supervision is that many full time students from small, homogeneous communities enter the field with little real life experience and limited exposure to cultural diversity. Before introducing these students/interns to the scope of practice, supervisors often must address the need to clarify personal versus professional values and to explain and model the basic principles of professional boundaries and the therapeutic relationship. For those students/interns who have had experience, supervisory tasks include addressing the need to move beyond a model of practice used in a prior agency position and to improve and diversify skills. While supervisory tasks can always create challenges of time and resource management, the impact of the COVID19 pandemic on service systems increased these challenges. Supervisors must constantly balance between their duties to the organization, to their staff and clients, to their profession, and to their students/interns.

In most states in the United States, once a social worker has achieved the master's level license, the law requires annual continuing education. Continuing education classes can help a licensed professional to earn the supervisory designation to their license, which then will require courses in supervisory theory and skills for license renewal. Social work agencies may also offer courses and training in supervisory practices to ensure a high quality of supervision for the agency staff. It is still the norm, however, for supervisors to be "eased" into the role without much formal training or education, other than the model of supervision experienced early in their own training. In contrast, there is specific training in Poland for the role of supervisor, and the function of supervision appears to be more consistent with a specific role designation than it is in the United States (Ministerstwo Rodziny i Polityki Społecznej 2021).

Research on supervision has been growing, but there are limitations given the nature of the topic. For example, research on supervision is conducted in a wide range of settings: business, health care, education, social work, and psychology. While there may be similarities among these supervisory situations, surely there are also differences. Much of the literature is self-report and therefore open to social desirability bias. Correlational designs are common even though the nature of supervision would be amenable to longitudinal designs. Measures tend to be perception/satisfaction ratings instead of objective measures and performance outcomes. In spite of these limitations, research has shown what characteristics are most highly rated among those deemed effective or competent supervisors (Marino 2011). In general, those deemed as effective or competent supervisors actively balance the competing roles: efficient administration; supportive responses to staff; up to date, relevant training and education; and involvement in advocacy and professional goals. Students/trainees highlighted the role modeling they saw in their supervisors, noting their availability and flexibility, openness to new ideas, and ability to demonstrate as well as discuss specific skills. Supervisors were seen as more competent when they offered constructive criticism in the context of a supportive relationship. Worthen and McNeil (1996) found that non-judgmental, validating behaviors enhance a supervisee's experiences. Barnett (2007) discussed the role of a safe environment which provides supervisees the opportunity to openly share ideas, concerns, and fears as well as to take some risks 
and try a new skill. In the words of Lawrence Shulman, competent supervisors are experts in encouraging work while reducing resistance (Sewell 2018).

Of the three basic functions of supervision-administration, education, and support, administration is usually the least favorite and support the most needed (Berger \& Quiros 2014, O’Donoghue et al. 2018). These two mentioned functions are often in conflict as it is challenging to support someone who at the same time may need administrative coercion. Very often administrative supervision helps an institution to maintain professional structure and compliance. However, there is an inherent conflict between respecting institutional rules and responding to a changing environment. If the role of a social worker is to be a leader and a change agent, then social workers should study the ever changing needs of their clients and routinely suggest appropriate policy and program modifications. Often, change meets with institutional resistance and requires special leadership skills to make the necessary reforms. The challenges confronting social workers in the twenty-first century make plain the need for changes in how we supervise and support those most critical to providing care (Vito \& Schmidt Hanbidge 2021).

Most of the literature concerning social work supervision in advocacy work involves issues that can be discussed during a regular supervisory meeting. During such meetings, a supervisee discusses how the well-being of their clients can be improved by advocacy action at the organizational level or on a more macro level such as city, state, or federal (Glosoff \& Durham 2010; Asakura \& Maurer 2018). In her work, McLaughlin (2009) mentioned three types of advocacy: instrumental, educational, and practical. In instrumental advocacy the social worker's action is at the level of systems responsible for the policies discussed. Educational advocacy informs others about the social problems that need to be addressed and suggests how these problems can be resolved. Educational advocacy is perhaps the kind that is most visible to the public. In practical advocacy the social worker is personally involved in activities on behalf of their clients.

Advocacy activities may take the form of political engagement including running for office. United States Senator Barbara Mikulski exemplifies this approach (Romaniuk 2013). Another form of political engagement is participation in demonstrations in front of the public and/or government offices or getting involved in different street protests and marches. Interestingly, most of the research papers concerning political engagement are published by specialists in the study of economics, public health, or anthropology. There are not many mentions of the supervisors of social workers engaged in political advocacy or setting an advocacy example for supervisees through political engagement.

\section{THE IMPORTANCE OF SELF-CARE IN SOCIAL WORK PRACTICE}

The COVID-19 pandemic ushered in a renewed focus on self-care for social workers. In response to the pandemic stressors, the National Association of Social Workers revised the professional code of ethics to include explicit language on the role of selfcare in ethical practice. The purpose of the code of ethics was amended in 2021 to read 
as follows:

Professional self-care is paramount for competent and ethical social work practice. Professional demands, challenging workplace climates, and exposure to trauma warrant that social workers maintain personal and professional health, safety, and integrity. Social work organizations, agencies, and educational institutions are encouraged to promote organizational policies, practices, and materials to support social workers' self-care. (NASW 2021)

The presence of self-care in the professional code of ethics elevates the concept to a value and principle of social work practice, much more than a recommendation or suggestion for practice. All social workers should now employ self-care strategies in both their professional practice as well as in the personal lives in all practice settings and all scopes of practice. The elevation of self-care logically is extended into the arena of supervision and foreshadows the use of reflective approaches for the supervisor to value and to model as well as to teach self-care to students and staff members.

Many authors concerned with the well-being of professionals who deal with social justice issues stress the importance of empathy in mental health services. It is important to be able to use compassion while advocating for vulnerable and marginalized populations. An especially interesting method of building emotional resiliency and empathy for clients is the method of Schwartz Rounds (Farr \& Barker 2017). This method refers to a special meeting of professionals who meet to discuss emotional, social and personal issues associated with client care. This intentional inclusion of emotional and personal issues can increase the amount of support offered to all involved in difficult care situations. Trauma-informed care is a logical next step in the discussion of the significance of self-care in social work practice (Knight 2013).

\section{TRAUMA INFORMED PRACTICE (TIC)}

Anda and coworkers (2006) found that among people who struggle with physical and mental health problems, there is a significant number who experienced traumatic events as children. Often, they first report health problems many years after the trauma experience, so the link between trauma and health impacts was overlooked. The studies that followed on the neurobiology of trauma and chronic stress in childhood confirmed a causal relationship between traumatic events and health problems later in life. The prevalence of adverse childhood experiences (ACE) created a new approach to health care in general. The subsequent studies showed that the number (score) of ACEs in someone's life can be a risk factor in developing different physical and mental health disorders. These results prompted a new approach in health care to create medical services that are informed by our knowledge of trauma. One of the primary attributes of this approach is to avoid re-traumatization while seeking help. Another central attribute of a trauma-informed approach is that all medical personnel must be trained in the effects of trauma on well-being. The physical structure, as well, has to be safe and accommodating of patients who may struggle from different forms of trauma (SAMHSA 2014). 
According to SAMHSA (2014), there are six guiding principles of trauma informed care (TIC): safety; trustworthiness and transparency; peer support and mutual selfhelp; collaboration and mutuality; empowerment voice and choice; and cultural, historical, and gender issues. Although the goal of creating a trauma informed approach to health care is well documented, it is still more an idea than established practice in many service settings (Sweeney \& Taggart 2018).

\section{REFLECTIVE AND TRAUMA INFORMED PRACTICE}

In general, during traumatic events people lose control over their choices or bodies. For people who were traumatized, any inequality of power may create conditions that could be re-traumatizing. This is why social workers need to know the characteristics of their client populations and why their supervisors have to be knowledgeable about the possibility of a history of trauma among both clients and supervisees. In a hierarchical institution, where a supervisor has control over the career of a supervisee, the inequality of power is inherent to the system. In trauma informed practice the goal is the collaboration with each staff member having equal power. In supervision, with the administrative role of a supervisor, such equality is difficult to achieve (Hair 2015; Berger et al. 2018). However, there are ways to accomplish a greater degree of equality. For example, a supervisor may suggest completing a certain assignment by supervisees and discussing with them how they approach and carry on the project. They can use their roles as educators and supporters, encourage critical thinking, and facilitate an introspective approach through asking questions instead of offering solutions to problems. This method is well known as reflective practice and is especially recommended when there is a need to learn about the problem that practitioner encounters (Cameron 2009, Grewiński \& Skrzypczak 2014). In reflective supervision, usually both the supervisor and supervisee can reflect on their part of the relationship. Instead of giving a lecture, the supervisor may ask questions and discuss the supervisee's ideas, while underscoring observed strengths and skills of supervisee (Kinman \& Grant 2017; Varghese et al. 2018).

There are significant similarities between the model of reflective supervision and trauma informed supervision. Years of practice in the fields of child welfare, children's mental health, and education led to the development of reflective supervision meant to educate practitioners on how to develop an effective relationship with parents and children (Perkowska-Klejman 2012). Instead of a hierarchical, one-way affiliation between supervisor and supervisee, it was established that a more egalitarian, two-way relationship better served those who work with families and children. The goal of this relationship was to model an open and trusting relationship between a practitioner and a client. A core function of their supervisory alliance was a reflective inquiry of practitioner performance. Using questions concerning both objective case presentation (what happened) and subjective practitioner feelings and believes (reactions vs. educated responses), the supervisor and supervisee can create safe space to learn and discuss the best intervention in a client's life. Years of this application of reflective supervision allowed for the development of evidence based practices that can be used 
in a much more recent model of trauma informed care. There are many resources to learn how to apply the best practice guidance for the reflective supervision. For example, the program Multiplying Connections created by the Health Federation of Philadelphia (2018) is often cited as a resource for building reflective and trauma informed supervision.

Trauma informed care seemingly adopted reflective supervision as the method of communication between supervisor and supervisee (Varghese et al. 2018; Romaniuk 2021). In 2017, Rankine from the University of Auckland presented a theoretical model for reflective supervision pointing out four different layers of practice: individual, organizational, relational and socio-political, and socio-cultural. Since asking questions is the most important part of this approach, we present examples of inquiry of each of the forth levels based on Rankine's work. At level one representing practitioners, the supervisor can ask how their cultural background may affect how they present the case report. How does the information they have learned correspond with their professional role? Can they see the situation differently, and how might this affect their actions? At level two, the organizational level, the supervisor may ask how the goals of their organization may affect practitioners' decisions concerning their intervention and with whom from the organization they can collaborate. Through these questions supervisees may recognize what assumptions concerning their employment are taken-for-granted and how to challenge them if necessary. On the third relational level, practitioners analyze their relationship with a supervisor as it serves as a base for any other relationships within their profession. They analyze their value system and their abilities to be open, honest, and empathetic. The practitioner is guided to recognize the system of power and control to be able to acknowledge that some people use their privileges at work whereas others are silenced because of their group vulnerability. The understanding of the role of power in organizational hierarchy may help in a search for equity and justice for both employees and the people that are served. Developing sensitivity in recognizing the role of power and privilege in social organizations is especially useful at the fourth level of practice, socio-political and socio-cultural context. Working with different populations of people with diverse socio-cultural backgrounds requires professional humility and an openness to experience different conditions of human existence. A supervisor may ask questions concerning the dominant culture and the messages that people receive from those in power. Practitioners may have to critically question their own beliefs and values concerning other people's needs and problems.

In the constantly changing environment of social work practice, it is difficult to apply well-established techniques and methods to serve people in need. Sometimes, the needs presented are separate from the real source of the problem. This is especially true in helping people with generational poverty, trauma, and oppression. For example, they may reveal problems with parenting or a marriage while the source of the problem may extend to the specifics of the underserved community that they came from. Reflective practice, as designed in 1983 by Donald A. Schön (see Cameron 2009), is a technique of learning about the needs of people that can be poorly recognized by social science professionals. There might be different reasons for insufficient knowl- 
edge: the social problems may be new or they may be the result of recent political and economic changes. What practitioners are subjected to might be related to unknown historical, cultural, and social conditions to which their clients have been exposed. Through the method of "reflecting in and on practice", a professional may gain new information. The technique of critical inquiry is helpful with the new approach of trauma informed care especially when the presenting problem is often separated from its real cause.

\section{TRAUMA INFORMED SUPERVISION}

Trauma informed care is not trauma therapy. It is an approach that is sensitive to the history of trauma in peoples' lives. Very often people who are looking for help do not want to address their history of trauma; rather, they want to talk about recent events in their lives. Only trained professionals may connect present difficulties with past history. This is why it is advised to ask for any possible events in the client's life that happened before the present difficulties to evaluate the possible triggers of current emotions and behaviors. There are different mental health problems that can be evoked by trauma. They are often related to low self-esteem and can lead to self-harming behaviors such as cutting and alcohol and drug abuse. People who experienced traumatic events in their childhood may develop eating disorders, different forms of somatization, and dissociative identity disorder. Mood and stress-related disorders are common (Knight 2018).

Social workers who work with people who have experienced trauma are exposed to hearing stories that affect their emotional well-being and may lead to experiencing vicarious trauma, secondary traumatic stress, or compassion fatigue, all of which can lead to burnout. These three different phenomena may have detrimental effects on a social worker's ability to thrive. The role of the supervisor is to observe any risk factors that may lead to those effects of trauma and recognize when a social worker may already be manifesting symptoms. Both forms of indirect trauma such as vicarious trauma and secondary traumatic stress have similar symptoms to post-traumatic stress disorder (PTSD). In the case of compassion fatigue, the clinician develops difficulties empathizing with the client, especially if there are problems with communication during therapy. To be better prepared to work with trauma survivors, social workers and other professionals need to practice self-care and build their own resiliency (Knight 2013; Butler et al. 2017; Kinman \& Grant 2017).

It has been recognized that when an institution follows the guidance of TIC, it reduces the manifestation of indirect trauma among professionals. One of the methods to introduce a TIC approach to the present system is to extend the TIC principles to the supervision of social workers and other professionals (Romaniuk \& Farkas 2021). Supervisors play a significant role in the implementation of TIC principles in their work with supervisees. As educators, they are able to explain the impact of trauma in a client's life and connect today's problems (such as addiction or homelessness) with the history of trauma. Supervisors may, in some instances, recognize the impact of previous trauma among staff. A supervisor may notice a pattern of avoidance on 
certain topics and then bring awareness to such issues through reflective discussion (Knight 2018). Reflective practice recognizes that a history of traumatic experience may affect the willingness of "using of self" in supervision (Ferguson 2018). A trusting and egalitarian supervisor-supervisee relationship in TIC may lead to less avoidance of reflection on difficult experiences.

A supportive relationship with a supervisor is also a form of self-care (Glassburn at al. 2019). A practitioner may experience stress from several sources, and the cumulating effect in everyday life can be overlooked. Professionals may blame themselves for coping poorly with challenges and push themselves to overcome the obstacles. Reflective supervision may help them recognize the stress they experience and analyze the best interventions to resolve their problems. Knowledge about the role of traumatic experiences in people's lives may help a supervisee to make the connection between present emotions and past stressors. This deep self-analysis will benefit their future work with others as it helps them to develop a better understanding of other people's struggles. Such supervision can lead to acquiring routines of self-reflection and to the recognition of warning signs for stress-related problems. Supervisors are in a role to suggest that a practitioner might include mindfulness techniques and other forms of body-oriented practices as part of self-care (Richards et al. 2010). A supervisor's modeling of self-care and supportive engagement may help a supervisee to avoid negative effects of trauma and, similar to clients' posttraumatic growth; a supervisee may experience "vicarious posttraumatic growth" that manifests in a better appreciation of their professional skills and abilities (Knight 2018).

The six principles of TIC may serve as guidance to any discussion between supervisor and supervisee. For example, the principle of safety underlines the importance of a safe place for open and honest discussion of all aspects of the supervisee's issues related to their work. Supervisees need to feel accepted and understood. The boundaries of the relationship and expectations concerning the relationship should be clear yet flexible (Knight 2018). The principle of trustworthiness and transparency encourages curiosity about the possibility of a supervisee's underlying history of trauma in responding to a client's present problems. The supervisor may bring the context of trauma to their conversations. Cultural, historical, and gender issues cannot be ignored. Social workers may deal with a diverse population of clients, and so they need to learn about the specificity of each group as a part of their cultural education. By the same token, the impact of culture, history and gender issues in the supervisee's and supervisor's lives are important. Some topics, due to the history of racism, sexism, homophobia and other forms of oppression, might be more difficult to bring into open discussion (Berger et al. 2018). However, to be honest and open, transparent, and trustworthy, a supervisor may address how diverse experiences affect the therapeutic relationship. Similarly, if there is a cultural difference between supervisor and supervisee, the differences in identity and cultural background should be discussed and how those differences could affect their relationship. Varghese, Quiros and Berger (2018) suggested using specific tools for culturally competent trauma-informed supervisors. These tools include locating oneself; engaging in dialogue; suspending judgments; identifying biases, and assumptions; and reflection and inquiry. Locating oneself, a 
self-assessment of one's own social identity, is a process of finding out how one social identity interacts with another person's identity, understanding their historical meaning and biases. Engaging in dialogue means maintaining an open discussion and sharing feelings and opinions; deep listening means listening to others and to your own reactions, your own belief system and gut feelings. Suspension of judgements refers to noticing your own judgement and try to see reality that is not changed by your judgement. Finally, after recognizing biases and assumptions, both people in supervision reflect on the process and what they learned from it to develop more questions relevant to the findings (Varghese et al. 2018). Throughout the entire process, the power imbalance is addressed and minimalized according to principles 3-5 of TIC (Berger et al. 2018).

A good example of the relevance of trauma informed supervision is in addiction treatment. There is a reciprocal cause-effect relationship between trauma and substance abuse: people who experience trauma often develop addiction and people who are under the influence of mind- altering substances exhibit behavior that is prone to traumatic occurrences (Jones \& Branco 2020). Due to the complex nature of problems in addiction treatment, the social worker's role is very demanding (Litwa-Janowska 2017). Clients often do not recognize their own progression of disorder; they resist change and do not trust the therapeutic process. Due to challenging work conditions, addiction social workers and counselors obtain the highest number of ethical violations compared to other professionals (Jones \& Branco 2020). With the higher stress at work, there is a greater demand for supervision in addiction treatment. While addressing clients' trauma, counselors may develop indirect trauma that should be elaborated on during supervisory sessions. Jones and Branco (2020) gave an example of a case study that can be discussed using the six principles of TIC as guidance. This kind of supervision helps the whole institution to apply TIC rules.

\section{ADVOCACY FOR SOCIETAL CHANGES}

One of the core values of social work practice in the United States is social justice; social workers challenge social injustice (McLaughlin 2009). Issues of equity and fairness are salient in today's society. People, in general, and students, in particular, are concerned about social justice and wish to take an anti-oppressive approach to history (Hair 2015; Knight \& Borders 2018) and, more importantly, to change how society works. There are social workers who see themselves as peaceful participants in the incremental transformation of a long-established system and others who demand more immediate change through political protests and demonstrations. There is a power struggle between a new and an old social order and a spectrum of views reflecting today's political and social conflicts. A change agent may experience different levels of institutional resistance, from relatively smooth policy debates to violent street confrontations with the police. The requirements of social justice often conflict with the realities of political power. Those who challenge and resist political power may pay a significant price for their beliefs.

Social workers, by nature of their professional values, must understand the effects 
of collective injustice in shaping today's society. The history of oppression and transgenerational trauma are topics that social workers cannot avoid (Knight \& Borders 2018). If the professional obligation to pursue social justice puts social workers in conflict with the law or otherwise endangers them, then there must be avenues to offer professional support for such situations. By design, the most appropriate support should be offered by social work supervision. However, not many social workers have ever been trained for such a role (Hair 2015). In fact, many organizations would rather train their employees how to follow their policies than motivate them to question their traditions. Social workers who seek to change society and to publicly address inequalities and inequities may suffer traumatic abuse and derision as a result of their advocacy. A greater understanding of the application of trauma-informed principles will help us to develop further guidelines for supervisory skills that will encourage advocacy and increase support to those who take overt, public steps towards social change.

\section{SUPERVISION AND EDUCATION OF SOCIAL WORK STUDENTS}

In addition to education, students of social work also need supervision for their practice. They can be exposed to the effects of trauma on peoples' lives during their field placements (Tarshis \& Baird 2019) and during classwork at a time when global events create political trauma (Sondel et al. 2018). Tarshis and Baird (2019) presented a good example of field placement supervision in Intimate Partner Violence (IPV) practice. There is a need to teach students how to develop resilience to the experience of indirect trauma while working with clients in an IPV setting and to recognize that trauma my affect them at different environmental levels. To do that, the authors (Tarshis \& Baird 2019) used both a TIC approach and ecological framework. In the ecological framework, students learn about the effects of trauma at personal, relational, community, and system levels. On the personal level, students consider their psychological vulnerability to indirect trauma. Depending on the students' past history of trauma, they may have different emotional skills in dealing with clients' history of abuse and suffering. Because of their predispositions, students are advised to self-assess their reactions to the stories they hear of clients' lives. In terms of relationships, students are encouraged to openly discuss their practical experiences with supervisors and to observe how their relationships improve when they are building mutual trust (Knight 2013). The supervisor may address cases of countertransference, when students describe their emotional responses to clients' stories. At the community level, students are trained to work in the environment where people are affected by traumatic events. Supervisors have weekly or bi-weekly meetings with students to assure that students have the necessary support in their practice. They empower students to exercise their own voice and choice concerning working with clients. At the systematic level, students participate in a learning process concerning the destigmatizing of trauma survivors individually and organizationally. They are educated about the role of racism, sexism, and different kinds of oppression on people from different social groups and about the transgenerational transmission of trauma. Supervisors may empower stu- 
dents to be engaged in global events that affect their population of clients or their own community (Mapp et al. 2019; Tarshis \& Baird 2019).

Sondel, Baggett and Dunn (2018) discussed how certain global political events may traumatize large populations of people. Students of social work, due to their mission to help those who cannot help themselves, are vulnerable to many forms of political trauma. Taking as an example recent political events in the United States, the authors voiced the opinion that educators cannot minimize or dismiss obvious demonstrations of systemic oppression while teaching young people. Students need to be empowered to question authorities and get involved in civic action to defend their values and their sense of justice and equality. A similar conclusion can be found in the work of Swanson and Szymanski (2020) concerning the \#MeToo Movement. They concluded that activism may help survivors of sexual assaults to heal from their traumatic experiences. However, they also emphasized that many activists experience emotionally challenging incidents for which they need support from other people. Successful advocates, who are honest and open about their personal experiences, may find some discomfort when they come up against professional boundaries in supervision. An example from Poland, of an activist and a healer further illustrates the ways in which advocacy can create a stressors and how the principles of trauma informed supervision can be used to support advocates for change.

\section{AN ACTIVIST AND A HEALER}

Elżbieta Podleśna (2020) wrote about her experiences of psychological abuse in an article concerning her work in the Center for Theatre Practices "Gardzienice" in Poland. This is a very explicit and heartbreaking description of emotional exploitation that she experienced at a young age for a period of five years. She also described a process of breaking a cycle of abuse and learning how to heal her trauma. She became a wellknown public figure through her activism for human rights. Recently, her advocacy work has been directed against the oppressive politics of the Catholic Church and Polish government toward women and LGBTQ communities in Poland (Holland 2021). Her most recent engagement was in helping refugees on the Polish-Belarussian border, the easternmost border of the European Union (Redakcja 2021). Professionally, she is an addiction and mental health therapist who uses a trauma-informed approach to her work. As an activist, she uses social media to bring public awareness of abuses by the police and right-wing politicians against marginalized groups of citizens.

With her activism, Podleśna exemplifies the power of the six principles of Trauma Informed Care. Since her presence in social media is open to everybody, her adherence to the guidance of TIC is clear. As a therapist she shares with others how she prepares herself and her office for a client's visit. She is concerned about the safety of people who join her in her public activities and talks with them about the possible outcomes of their advocacy actions. On her social media platform she publishes helpline phone numbers, available political supporters, and legal advocates. She informs everybody about her motives and plans of action. She transparently presents her opinions and 
her worries and discusses her boundaries. She works collaboratively with other activists, appreciating the help and support of others. She is able to ask for and offer help. She acknowledges and validates other people's efforts in working toward common goals. Podleśna uses social media, radio, press, and television, street demonstrations, and any possible form of communication to verbalize her social and political messages. It seems like there is no power that could limit her freedom of speech. She uses international resources if local resources seem insufficient. Podleśna calls herself a feminist but she also has an awareness that this term means different things for different people. She calls herself leftist, although she criticizes left party leaders for their questionable motives. She criticizes authorities of the Catholic Church, but she has empathy for Catholics; she defends members of all marginalized groups, including the LGBTQ community.

What is especially interesting about the choices of Elżbieta Podleśna is that since she is fully aware that a significant amount of the power of Polish political leaders comes from secrets and lies, she is truthful and transparent in all of her actions. She shares in social media not only her political engagement but also small things that she does as a private person to heal from the abuse she receives from her enemies. And, judging from the last two elections, she still has more political opponents than supporters.

\section{CONCLUSION}

Those who choose a career in social work are dedicated to building a better, more equitable society. However, the road to social change is increasingly confrontational and fraught with consequences in the workforce, among family members, and in the general society. Supervisory practices have long supported advocacy efforts but have not been as explicit in listing the possible costs and consequences of taking an advocacy position - especially if this position is about a controversial societal issue. For example, in the United States, individuals who have provided leadership and advocacy for COVID-19 precautions have been threatened and harassed. While advocates, especially political protestors, often faced police action and detainment, few had their families threatened or their homes surrounded by angry mobs as did the head of the public health department in Ohio (Spector 2020). Supervisors, who are invested in social change and advocacy strategies, will do well to use the principles of trauma informed care and trauma informed supervisory practices to work with younger professionals who are eager to be a part of social change strategies. Trauma informed care practices are no longer only for therapeutic practice with clients. They should be introduced as part of supervisory education for those who will train and guide newly emerging professionals who have the enthusiasm, energy, and courage to push for social change. 
FUNDING: This research received no external funding.

CONFLICT OF INTEREST: The authors declare no conflict of interest.

\section{REFERENCES}

Anda, Robert F., Vincent J. Felitti, J. Douglas Bremner, et al. 2006. “The Enduring Effects of Abuse and Related Adverse Experiences in Childhood. A Convergence of Evidence from Neurobiology and Epidemiology.” European Archives of Psychiatry and Clinical Neuroscience 256(3):174-186. DOI: 10.1007/s00406-005-0624-4

Asakura, Kenta \& Katherine Maurer. 2018. "Attending to Social Justice in Clinical Social Work: Supervision as a Pedagogical Space.” Clinical Social Work Journal 46(1/2): 289-297. DOI: 10.1007/s10615-018-0667-4

Berger, Roni \& Laura Quiros. 2014. “Supervision for Trauma-Informed Practice.” Traumatology 20(4):296-301. DOI:10.1037/h0099835

Berger, Roni, Laura Quiros, \& Jamie R. Benavidez-Hatzis. 2018. “The Intersection of Identities in Supervision for Trauma-Informed Practice: Challenges and Strategies.” The Clinical Supervisor 37(1):122-141. DOI:10.1080/07325223.2017.1376299

Bernard, Janine M. \& Rodney K. Goodyear. 2004 Fundamentals of Clinical Supervision. Third Edition. Needham Hts. MA: Allyn \& Bacon.

Butler, Lisa D, Janice Carello, \& Eugene Maguin. 2017. “Trauma, Stress, and Self-Care in Clinical Training: Predictors of Burnout, Decline in Health Status, Secondary Traumatic Stress Symptoms, and Compassion Satisfaction.” Psychological Trauma 9(4):416-424. DOI: 10.1037/tra0000187.

Cameron, Mark. 2009. "Review Essays: Donald A. Schön. The Reflective Practitioner: How Professionals Think in Action. New York: Basic Books, 1983.” Qualitative Social Work 8(1):124-129. DOI: 10.1177/14733250090080010802

Farr, Michelle \& Rhiannon Barker. 2017. “Can Staff Be Supported to Deliver Compassionate Care Through Implementing Schwartz Rounds in Community and Mental Health Services?” Qualitative Health Research 27(11):1652-1663. DOI: $10.1177 / 1049732317702101$

Ferguson, Harry. 2018. "How Social Workers Reflect in Action and when and why They Don't: The Possibilities and Limits to Reflective Practice in Social Work.” Social Work Education 37(4): 415-427. DOI: 10.1080/02615479.2017.1413083

Glassburn, Susan, Lisa E. McGuire, \& Kathy Lay. 2019. "Reflection as Self-Care: Models for Facilitative Supervision.” Reflective Practice 20(6): 692-704, DOI: 10.1080/14623943.2019.1674271

Glosoff, Harriet L. \& Judith C. Durham. 2010. “Using Supervision to Prepare Social Justice Counseling Advocates.” Department of Counseling Scholarship and Creative Works. 98. Retrived November 21, 2021. (https://digitalcommons.montclair.edu/ counseling-facpubs/98).

Grewiński, Mirosław \& Bohdan Skrzypczak. 2014. „Superwizja Pracy Socjalnej.” WSP, Warszawa. Retrieved September 13, 2021 (http://mirek.grewinski.pl/wp-con- 
tent/uploads/2014/10/Superwizja_pracy_socjalnej.pdf).

Hair, Heather J. 2015. “Supervision Conversations about Social Justice and Social Work Practice.” Journal of Social Work 15(4):349-370. DOI: 10.1177/1468017314539082 Health Federation of Philadelphia. 2018. Multiplying Connections. Retrieved September 13, 2021 (https://healthfederation.org/Connections).

Holand, Agnieszka. 2021. „Elżbieta Podleśna Swoim Wielkim Sercem Ogarnia i Ludzi, i Zwierzęta." Gazeta Wyborcza, Wysolkie Obcasy, September 10. Retrived November 21, 2021 (https://www.wysokieobcasy.pl/wysokie-obcasy/7,100865,27654989,agnieszka-holland-elzbieta-podlesna-swoim-wielkim-sercem.html).

Jones, Connie T. \& Susan F. Branco. 2020. "Trauma-Informed Supervision: Clinical Supervision of Substance Use Disorder Counselors.” Journal of Addiction and Offender Counseling Issues 41: 2-17.

Kinman, Gail \& Louise Grant. 2017. "Building Resilience in Early-Career Social Workers: Evaluating a Multi-Modal Intervention.” The British Journal of Social Work 47(7): 1979-1998. DOI: 10.1093/bjsw/bcw164

Knight, Carolyn. 2013. "Indirect Trauma: Implications for Self-Care, Supervision, the Organization, and the Academic Institution.” The Clinical Supervisor 32(2): 224243. DOI: $10.1080 / 07325223.2013 .850139$

Knight, Carolyn. 2018. "Trauma-Informed Supervision: Historical Antecedents, Current Practice, and Future Directions.” The Clinical Supervisor 37(1): 7-37. DOI: 10.1080/07325223.2017.1413607

Knight, Carolyn \& DiAnne Borders. 2018. "Trauma-Informed Supervision: Core Components and Unique Dynamics in Varied Practice Contexts." The Clinical Supervisor 37(1): 1-6. DOI: 10.1080/07325223.2018.1440680

Litwa-Janowska, Agnieszka. 2017. „Superwizja - Rola, Stan Obecny, Oczekiwania Środowiska." Uzależnienia 3(79): 27-31.

Mapp, Susan, Jane McPherson, David Androff, \& Shirley Gatenio Gabel. 2019. “Social Work is a Human Rights Profession.” Social Work 64(3): 259-269.

Marino, Reshelle C. 2011. The influence of Specialization-Specific Supervision on School Counselors' Perceptions of Preparedness, Professional Identity, and Perceived Supervisor Effectiveness. University of New Orleans Theses and Dissertations. 1413. Retrieved September 13, 2021 (https://scholarworks.uno.edu/td/1413).

McLaughlin, Anne Marie. 2009. "Clinical Social Workers: Advocates For Social Justice.” Advances in Social Work 10(1): 51-64. DOI: 10.18060/209

Ministerstwo Rodziny i Polityki Społecznej. 2021. Superwizja Pracy Socjalnej. Retrived Nov. 21, 2021 (https://www.gov.pl/web/rodzina/superwizja-pracy-socjalnej).

National Association of Social Workers. 2021. Code of Ethics, 2021 Revisions. Retrieved September 13, 2021 (https://www.socialworkers.org/LinkClick.aspx?fileticket $=$ fxAeCri2U6c\%3D\&portalid $=0$ ).

O’Donoghue, Kieran, Peace W Y Ju, \& Ming-sum Tsui. 2018. “Constructing an Evidence-Informed Social Work Supervision Model.” European Journal of Social Work 21(3): 348-358. DOI: 10.1080/13691457.2017.1341387

Perkowska-Klejman, Anna. 2012. „Refleksyjna Praktyka w Pracy Pedagoga Szkolnego.” APS. Ruch Pedagogiczny 3:101-116. 
Podleśna, Elżbieta. 2020. „Przemoc dzieje się w ciszy.” Dwutygodnik.com. October. Retrived July 25, 2021 (https://www.dwutygodnik.com/artykul/9173-przemocdzieje-sie-w-ciszy.html).

Redakcja. 2021. „Elżbieta Podleśna: Hierarchowie Kościoła Katolickiego Mają Dziś Wpływ na Sądy w Polsce.” NaTemat, Oct. 24. Retrived Nov. 21, 2021 (https:// natemat.pl/380291, elzbieta-podlesna-o-kosciele-i-prawach-kobiet-u-jacka-palasinskiego).

Richards, Kelly, C. Estelle Campenni, \& Janet Muse-Burke. 2010. "Self-Care and Well-Being in Mental Health Professionals: The Mediating Effects of Self-Awareness and Mindfulness.” Journal of Mental Health Counseling 32(3):247-264. DOI: 10.17744/mehc.32.3.0n31v88304423806

Romaniuk, Richard. 2013. „Senator Barbara Mikulski.” Pp. 217-233 in Kobiety w Pracy Socjalnej, edited by A. Kotlarska-Michalska. Poznań: Wydawnictwo Naukowe UAM.

Romaniuk, Jarosław R. 2021. “Superwizyjny Sherlock Holmes. Wywiad z Superwizorem Pracy Socjalnej w Obszarze Handlu Ludźmi.” Niebieska Linia 2: 23-24.

Romaniuk, Jarosław R. \& Kathleen J. Farkas. 2021. „Terapia Zorientowana na Traumę w Placówkach Ochrony Zdrowia.” Lekarz Wojskowy 99(4): 182-190.

Sewell, Karen. 2018. "Illuminating Clinical Supervision-Past, Present and Future: An Interview with Dr. Lawrence Shulman.” Clinical Social Work Journal 46: 374-377.

Sondel, Beth, Hannah C. Baggett, \& Alyssa H. Dunn. 2018. "For Millions of People, this is Real Trauma: A Pedagogy of Political Trauma in the Wake of the 2016 U.S. Presidential Election.” Teaching and Teacher Education 70: 175-185. DOI: 10.1016/j.tate.2017.11.017

Spector, Harlan. 2020. “Dr. Amy Acton Has Been Calming and Competent; The Vicious Attacks on Her Have Been Madness.” The Capitol Journal. Retrieved September 13, 2021 (https://ohiocapitaljournal.com/2020/06/15/dr-amy-acton-has-beencalming-and-competent-the-vicious-attacks-on-her-have-been-madness/).

Strauss Swanson, Charlotte \& Dawn M. Szymanski, 2020. „From Pain to Power: An Exploration of Activism, The \#Metoo Movement, and Healing from Sexual Assault Trauma.” Journal of Counseling Psychology 67(6): 653-668. DOI: 10.1037/ cou0000429

Substance Abuse and Mental Health Services Administration. 2014. “SAMHSA's Concept of Trauma and Guidance for a Trauma-Informed Approach.” HHS Publication No. (SMA) 14-4884. Rockville, MD: Substance Abuse and Mental Health Services Administration.

Sweeney, Angela \& Danny Taggart. 2018. “(Mis)understanding Trauma-Informed Approaches in Mental Health.” Journal of Mental Health 27(5): 383-387. DOI: 10.1080/09638237.2018.1520973

Tarshis, Sarah \& Stephanie L. Baird. 2019. “Addressing the Indirect Trauma of Social Work Students in Intimate Partner Violence (IPV) Field Placements: A Framework for Supervision.” Clinical Social Work Journal 47: 90-102. DOI: 10.1007/ s10615-018-0678-1

Timor-Shlevin Shachar, Orly Benjamin. 2021. “The Tension between Managerial and 
Critical Professional Discourses in Social Work", Journal of Social Work 21(4):951969. DOI: $10.1177 / 1468017320949359$

Varghese, Rani, Laura Quiros, \& Roni Berger. 2018. "Reflective Practices for Engaging in Trauma-Informed Culturally Competent Supervision.” Smith College Studies in Social Work 88(2): 135-151. DOI: 10.1080/00377317.2018.1439826

Vito, Rosemary \& Alice Schmidt Hanbidge. 2021. "Teaching Social Work Leadership and Supervision: Lessons Learned from On-Campus and Online Formats.” Journal of Social Work Education. DOI: 10.1080/10437797.2021.1932650

Wonnacott, Jane. 2011. Mastering social work supervision. London: Jessica Kingsley. Worthen, Vaughn \& Brian W. McNeill. 1996. "A Phenomenological Investigation of “Good" Supervision Events." Journal of Counseling Psychology 43(1): 25-34. DOI: $\underline{10.1037 / 0022-0167.43 .1 .25}$

\section{BIOGRAPHICAL NOTE}

Jarosław R. Romaniuk, PhD, LISW-S, LICDC, is a researcher and educator. Currently he works as a fulltime lecturer at the Mandel School of Applied Social Sciences. From 2004 to 2015 he worked as a social worker at the Louis Stokes Cleveland Department of Veterans Affairs Medical Center. He also worked in the School of Medicine, Case Western Reserve University as a neuroscientist. His experience at the VA has led him to participate in national VA committees and the National Association of Social Workers in Ohio. He was also involved locally, as a Board member of The Alcohol, Drug Addiction and Mental Health Services (ADAMHS) Board of Cuyahoga County (2010-2017).

Kathleen J. Farkas, Ph.D. LISW-Supv. is an Associate Professor of Social Work at the Jack, Joseph and Morton Mandel School of Applied Social Sciences, Case Western Reserve University, Cleveland, Ohio USA. She has extensive clinical and research experience in the areas of mental health and addictions assessment and treatment. Dr. Farkas a long time interest in substance use issues among older adults and women and her work has focused on addictions and mental health issues among those incarcerated in jails and prisons. Recently she has been involved in research, teaching and publications using animal assisted interventions in mental health and addictions. She is the chairperson of the Mandel School's direct practice faculty as well as the specialization faculty for substance use disorders and recovery.

OPEN ACCESS: This article is distributed under the terms of the Creative Commons Attribution Non-commercial License (CC BY-NC 4.0) which permits any non-commercial use, and reproduction in any medium, provided the original author(s) and source are credited. 
